\title{
Verb placement in clauses with initial adverbial maybe
}

\author{
Kristine Bentzen \\ UiT The Arctic University of Norway
}

\section{Introduction}

The Scandinavian languages are generally verb second (V2) languages with the finite verb in the second position. However, there are certain exceptions to the V2 rule, and one of these involve main clauses with the adverb maybe in a clause-initial position. In such clauses, V2 tends to be optional (cf. among others Faarlund et al. 1997 and Westergaard 2009 for Norwegian, Platzack 1986, 1998, Teleman et al. 1999 and Andréasson 2002 for Swedish, Rögnvaldsson and Thráinsson 1990 for Icelandic and Thráinsson et al. 2004 for Faroese). This optionality is illustrated here with a Norwegian example (from Faarlund et al. 1997:814, my translations):

(Norwegian)

$$
\begin{aligned}
& \text { maybe have they seen it before } \\
& \text { b. Kanskje de har sett det for. } \\
& \text { maybe they have seen it before }
\end{aligned}
$$

'Maybe they have seen it before.'

Word order in such clauses has been tested in Denmark (ten locations), the Faroe Islands (six locations) and in four locations in Eastern Norway (Kirkenær, Drevsjø, Stange, and Brekkom). The relevant questions involve (i) the position of the verb: V2 (subject-verb inversion), V-to-I movement (verb movement across negation but not the subject), or verb in situ, and (ii) whether type of subject (pronoun vs. DP) has any influence on verb placement.

In Denmark and Norway clauses with initial adverbial maybe were tested with respect to all these variables (V2, V-to-I, verb in situ and DP vs. pronominal subject). In the Faroe Islands, V2 vs. V-to-I was tested, and only pronominal subjects were included. 


\section{Results}

\subsection{Nordic Syntax Database (NSD)}

Word order in sentences with clause-initial maybe was investigated in Danish, Faroese and at the four locations in Norway. In Denmark and Norway such clauses with V2 were tested with both pronominal subjects and DP subjects (here illustrated with Danish examples in (2a - b)). In Faroese they were tested with a pronominal subject, as shown in (2c):

(\#315) (Danish)

maybe comes he not

b. Måske kommer Peter ikke.

(\#319) (Danish)

maybe comes Peter not

'Maybe he/Peter won't come.'

c. Kanska fara vit á flot ímorgin. (\#315) (Faroese)

maybe go we on sea tomorrow

'Maybe we'll go to the sea tomorrow.'

In clauses with pronominal subjects, V2 is basically accepted in these contexts in all locations. Note however, that in certain locations in the North of the Faroes (Viðareiði and Fulgafjørður) as well as in Drevsjø in Norway, this example only received a medium score. The maps below show judgments for example (2a) (in Norway and Denmark) and (2c) (in the Faroe Islands): 


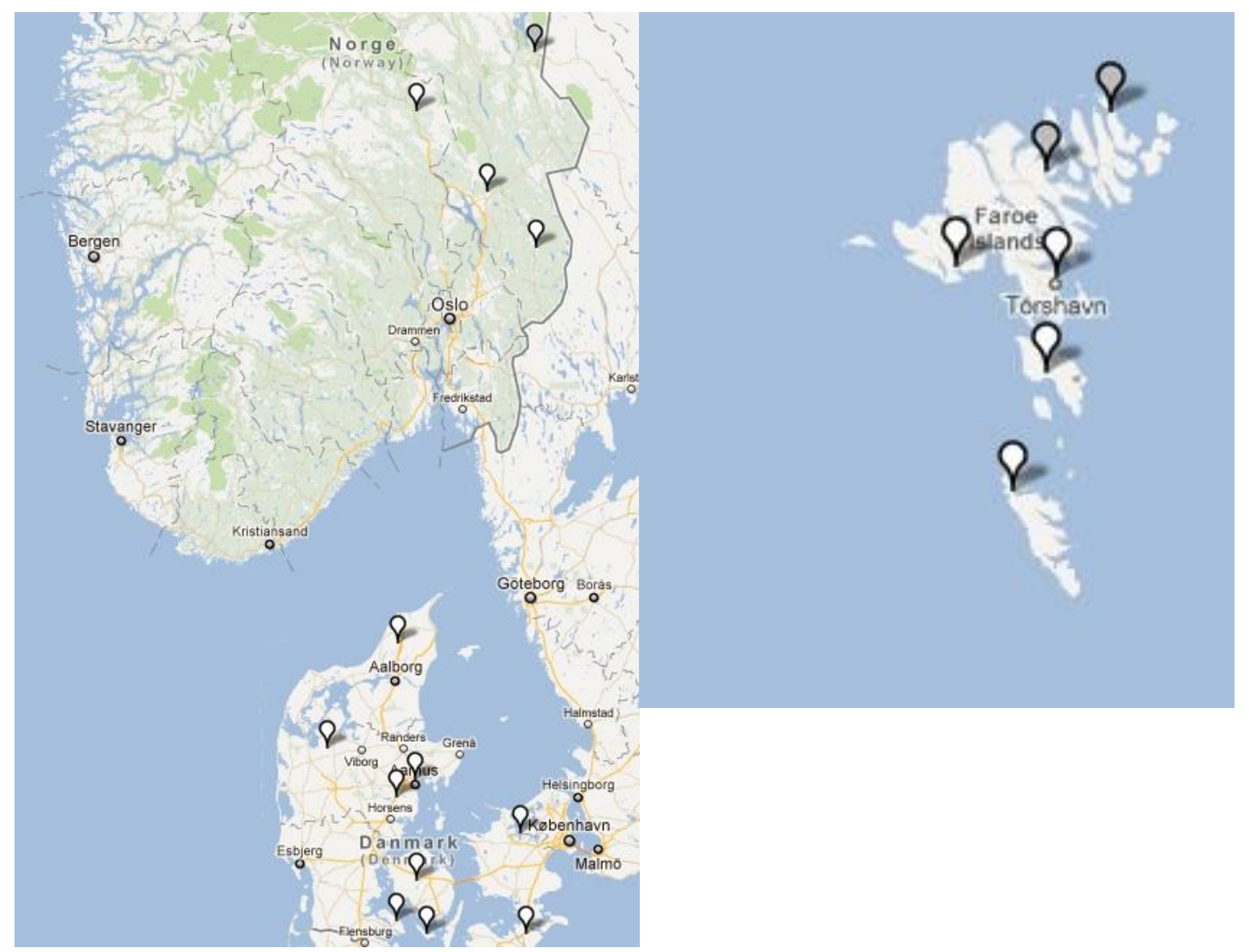

Maps 1 - 2: Judgments of V2 in clauses introduced by maybe with pronominal subjects

(\#315:Måske kommer han ikke. 'Maybe he won't come.' ' Kanska fara vit á flot í morgin 'Maybe we'll go to the sea tomorrow.')

(White $=$ high score $;$ grey $=$ medium score $)$

Interestingly, while V2 is also accepted with DP subjects in these clauses in Denmark, this is rejected in all the four Norwegian locations where this was tested (corresponding clauses were not tested in the Faroe Islands). The map below shows judgments for example (2b): 


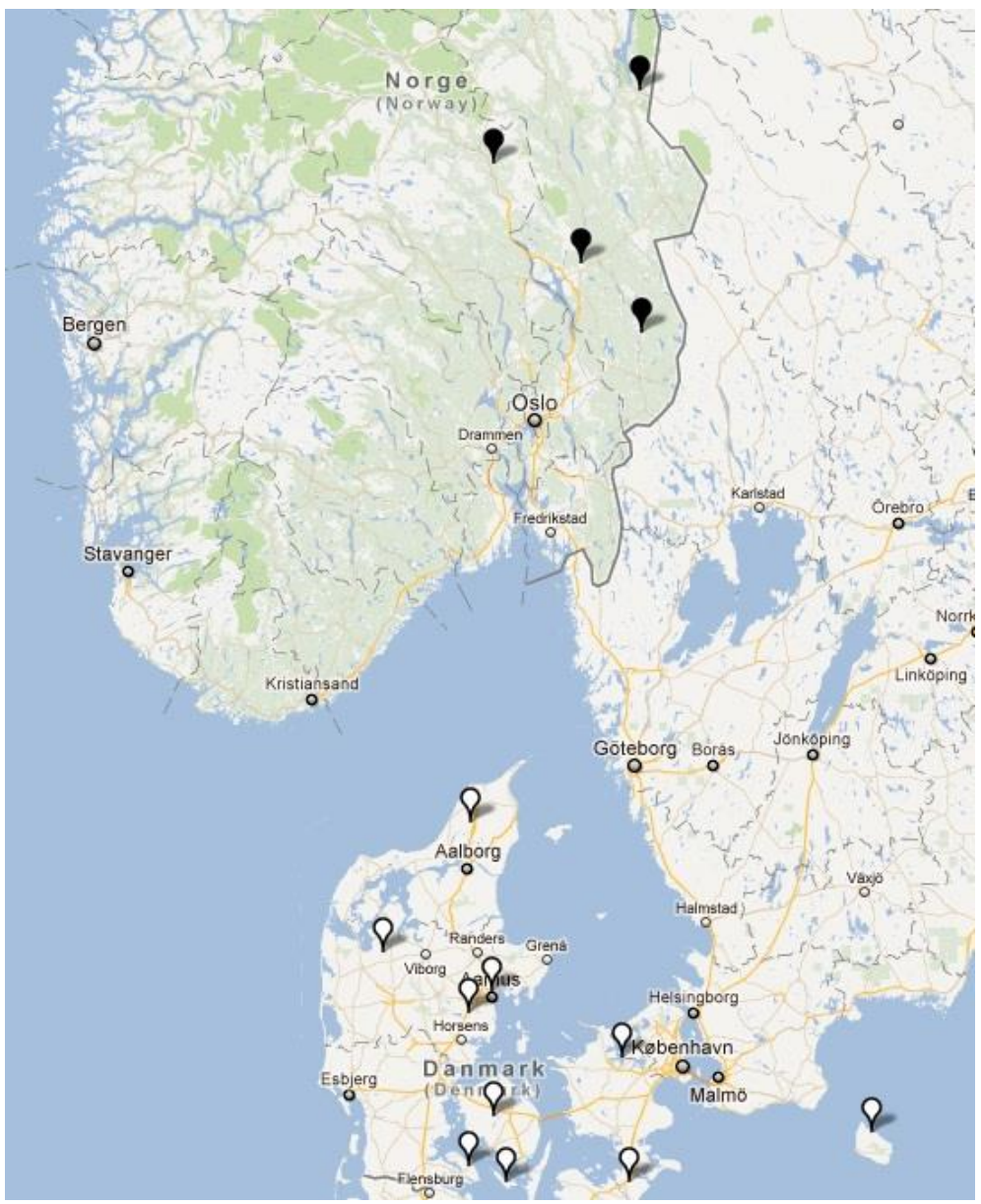

Map 3: Judgments of V2 in clauses introduced by maybe with DP subjects (\#319: Måske kommer Peter ikke. 'Maybe Peter won't come.')

(White = high score; black = low score $)$

In Denmark and Norway, V-to-I movement in such clauses was also investigated, as illustrated in (3):

(3) a. Måske han kommer ikke. (\#314) (Danish)

maybe he comes not

b. Måske Peter kommer ikke. (\#317) (Danish)

maybe Peter comes not

'Maybe he/Peter won't come.'

This word order was generally rejected in Denmark and Norway, regardless of type of subject (with the exception of Vestjylland and Østjylland for (3a) and Fyn for (3b)): 


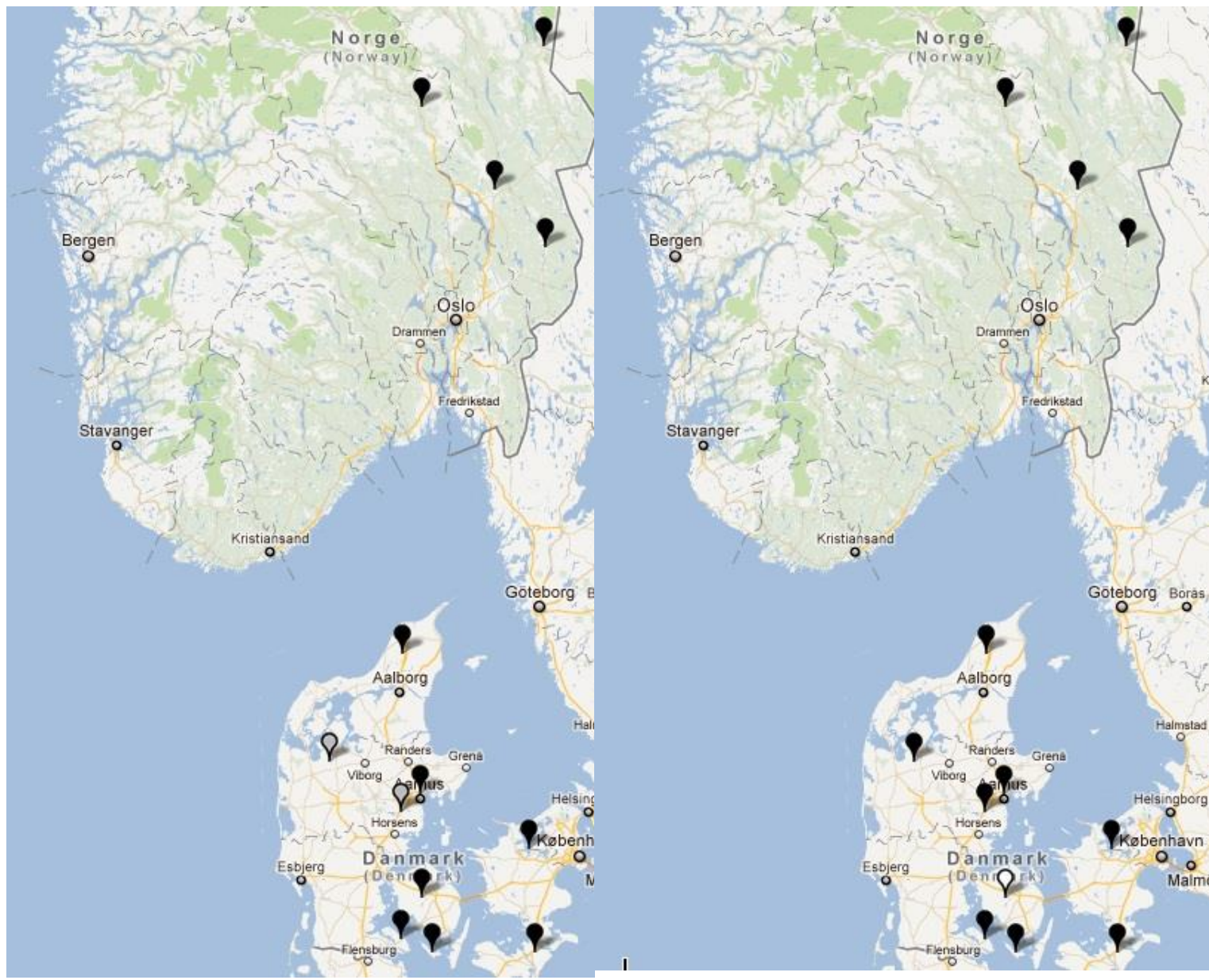

Maps 4 - 5: Danish and Norwegian judgments of V-to-I in clauses introduced by maybe with pronominal subjects (\#314: Måske han kommer ikke. 'Maybe he won't come.') and DP subjects (\#317: Måske Peter kommer ikke. 'Maybe Peter won't come.').

$($ White $=$ high score $;$ grey $=$ medium score $;$ black $=$ low score $)$

Clauses introduced by adverbial maybe but without (clear) verb movement were tested in Denmark and in the above-mentioned four locations in Norway with the examples in $(4 a-b)$, and in the Faroe Islands with (4c). Again, both pronominal and DP subjects were included in Denmark and Norway ((4) and (5) respectively). In this condition, there are two different positions available for the subject: before or after the negation:

(4)

$\begin{array}{lllll}\text { a. Måske han ikke } & \text { kommer. } & \text { (\#313) (Danish) } \\ \text { maybe he not } & \text { comes } & \\ \text { b. Måske ikke han } & \text { kommer. } & \text { (\#316) (Danish) } \\ \text { maybe not he } & \text { comes }\end{array}$

'Maybe he won't come.' 
c. Kanska vit fara á flot ímorgin. (\#314) (Faroese)

maybe we go on sea tomorrow

'Maybe we'll go to the sea tomorrow.'

(5) a. Måske Peter ikke kommer. (\#318) (Danish)

maybe Peter not comes

b. Måske ikke Peter kommer. (\#320) (Danish)

maybe not Peter comes

'Maybe Peter won't come.'

Clauses without verb movement are generally accepted in Norway, regardless of the type of subject involved, and also regardless of the position of the subject with respect to negation. However, in Danish, lack of verb movement/V2 is rejected or degraded in these types of clauses. Contexts where the subject appears in a post-negation position are generally rejected, while contexts with the subject in a prenegation position tend to get a medium score (and even get a high score in Nordjylland, Als, and Vestjylland). (The relative position of the subject with respect to negation will not be discussed further in this chapter; see Bentzen 2014). The judgment patterns in Denmark and Norway are illustrated in the maps below with judgments of sentences with the subject in the pre-negation position, ((4a) and (5a)): 


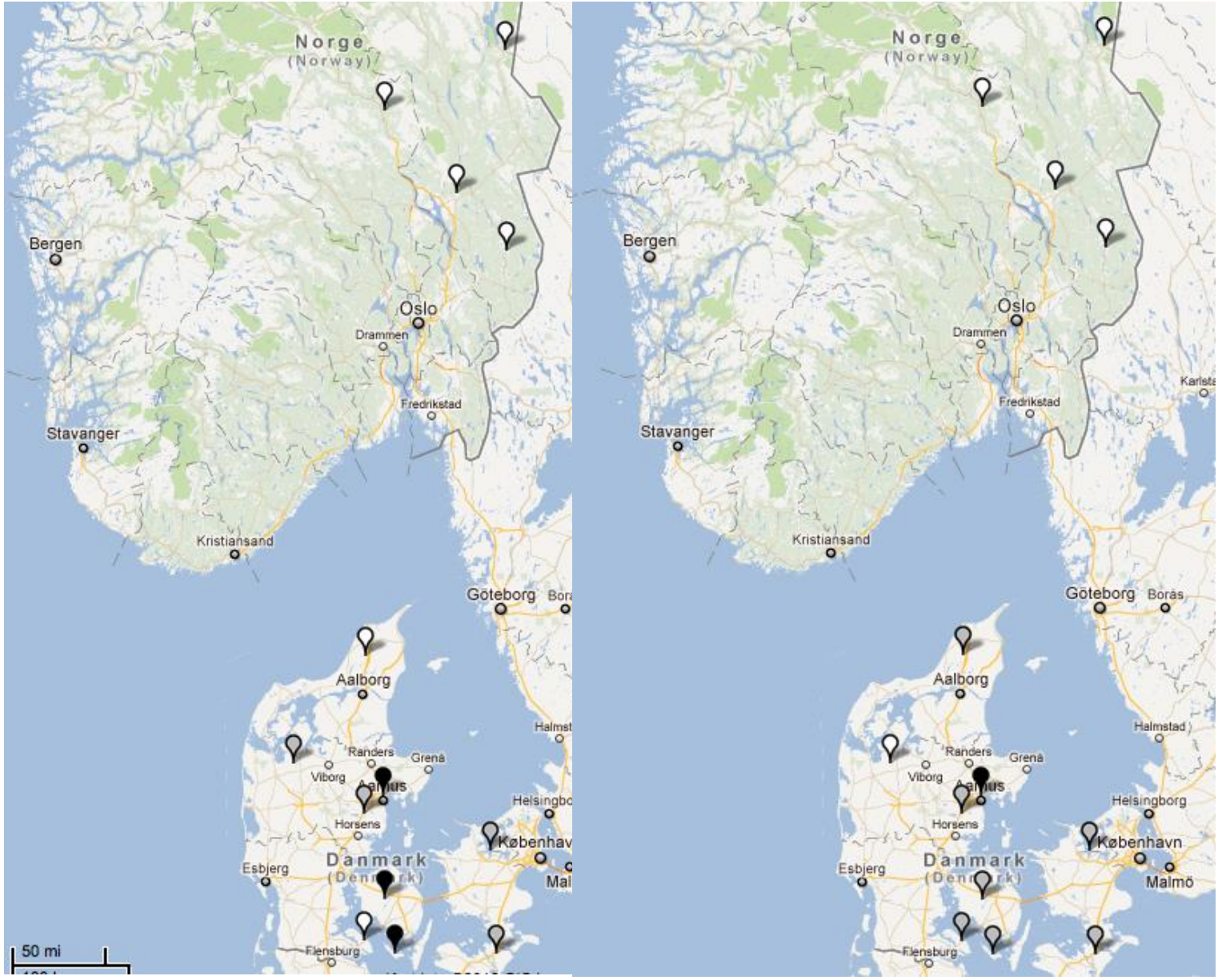

Maps 6 - 7: Danish and Norwegian judgments of clauses introduced by maybe without verb movement.

Map 6: pronominal subjects in pre-negation position (\#313: Måske han ikke kommer. 'Maybe he won't come.')
Map 7: DP subjects in pre-negation position (\#318: Måske Peter ikke kommer. 'Maybe Peter won't come.').

$($ White $=$ high score $;$ grey $=$ medium score $;$ black $=$ low score $)$

Similary, in the Faroe Islands, this word order is also quite frequently accepted. It receives a high score in half of the locations (Hvalba, Viðareiði, and Fulgafjørður), and a medium score in the other half (Tórshavn, Sandur, and Miðvagur): 


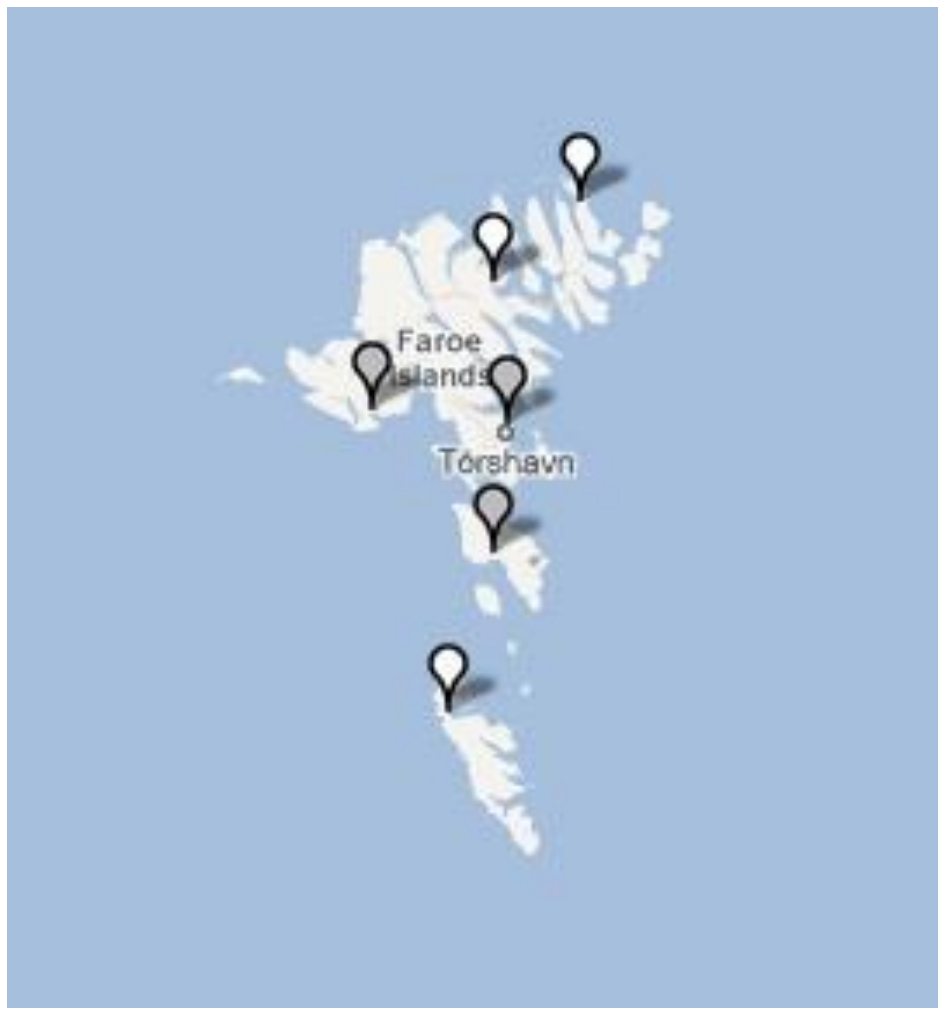

Map 8: Faroese judgments of V-to-I in clauses introduced by maybe with pronominal subjects (\#314: Kanska vit fara á flot í morgin. 'Maybe we'll go to the sea tomorrow.')

(White = high score $;$ grey = medium score $)$

\subsection{Nordic Dialect Corpus (NDC)}

We also find examples of non-V2 word orders in clauses with 'maybe' in the prefield in the Nordic Dialect Corpus. Searches were run in the corpus for all five languages (Norwegian, Swedish, Danish, Faroese, and Icelandic) picking out: (i) clause-initial 'maybe' immediately followed by a finite verb, (ii) clause-initial 'maybe' immediately followed by nominal element, and (iii) clauses with 'maybe' preceded by up to four non-verbal elements. The goal of these searches where to identify the distribution of the following three word order patterns:
(6) i. 'maybe Verb’ (V2)
ii. 'maybe $\mathrm{XP}$ ' (non-V2)
iii. 'XP-maybe' (non-V2)

For Danish, Faroese, and Icelandic, the searches only returned a handful of relevant examples in each of these languages (three in Danish and in Icelandic, five in Faroese). Moreover, within each language, the three examples instantiated all of the three word orders in (6). This is illustrated in (7) - (9):

(7) måske kan de- ka- kan de vende tilbage (Danish)
maybe can they ca can they turn back
'Maybe they can return.' (bornholm6)


(8) so kanska vit fara at hyggja (Faroese)

so maybe we go to see

'Then we might go to look at it.' (sandur_s9)

(9) maður kannski hefur heyrt um svona fátækustu hlutana (Icelandic)

man maybe has heard about like poorest parts.the

'I might have heard about the poorest areas.' (Iceland_a1)

Given this, it is not possible to make any further generalizations for Danish, Faroese, and Icelandic about word order in these constructions based on the data from NDC.

In Norwegian and Swedish, however, we see clear tendencies with respect to word orders in these constructions. In Norwegian, the search returned 126 examples, of which 122 were instances of non-V2 word order. Of these, 99 had the order illustrated in (6ii), with maybe in clause-initial position, followed by the subject (96 pronominal subjects and 2 DP subjects) or some other non-verbal element (1 example with an adverbial). Examples are provided in (10).

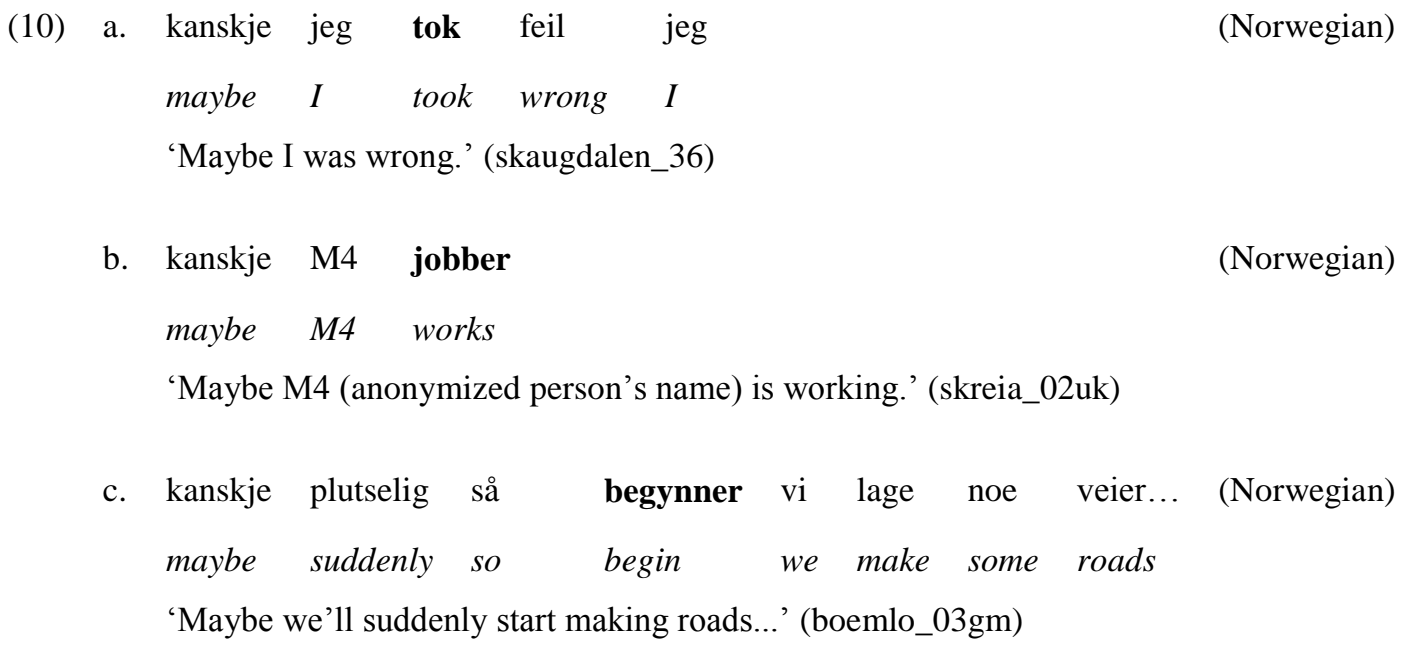

23 out of the 122 instances with non-V2 word order display the pattern in (6iii), with maybe in second position, preceded by the subject ( 8 pronominal subjects and 1 DP subjects) or some other non-verbal element (12 with an adverbial or a conjunction, and 2 with an object), as illustrated in (11). 
$\begin{array}{rlllllll}\text { (11) a. de } & \text { kanskje } & \text { slapp } & \text { det } & \text { litt } & \text { for langt } & \text { (Norwegian) } \\ & \text { they maybe let } & \text { it } & \text { little too long } & \end{array}$

'Maybe they let it go too far.' (vang_03gm)

b. kjøkemesteren kanskje var nå ikke så hvis (Norwegian)

chef.the maybe was now not so if

'Maybe the chef wasn't so bad.' (hyen_ma_02)

c. så kanskje du ikke klarer det
so maybe you not manage it

(Norwegian)

'Maybe you won't manage it.' (boemlo_03gm)

A search for the pattern in (6i), initial maybe followed by a finite verb, the V2 word order, returned four hits in Norwegian, all provided in (12). (Note that in (12a), the speaker interrupts herself, so it is difficult to determine what the actual word order would have been in a completed clause):

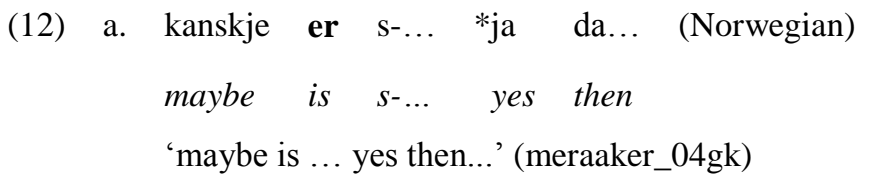

b. men kanskje er det... (Norwegian)

but maybe is it

'But maybe it is...' (oppdal_01um)

c. ja kanskje hadde det gått an å fått til noe (Norwegian) yes maybe had it gone PRT to get to something

'Yes, maybe it would have been possible to get something going' (selbu_01um)

d. ja nei kanskje låter det... (Norwegian)

yes no maybe sounds it

'Yes, maybe it sounds...' (lavangen_01um)

As is clear from these findings, non-V2 clearly is the preferred word order in these types of clauses in Norwegian in the Nordic Dialect Corpus. As much as 122 out of 126 (97\%) clauses with initial maybe display a non-V2 word order. Furthermore, among the 122 examples with the non-V2 word order, pattern (6ii), where maybe is the very initial element in the clause, exemplified in (10) is by far the most frequent pattern $(81 \%, 99 / 122)$. 
Turning to Swedish, the same set of searches returned 62 examples. Just like in Norwegian, we see a strong preference for the non-V2 word order in the Swedish data in the Nordic Dialect Corpus. Only two $(3 \%)$ out of the 62 examples are potential V2 contexts. Among the 60 non-V2 examples, the vast majority (57 examples, 95\%) displays the pattern in (6iii), where maybe is preceded by the subject (28, all pronominal subjects) or some other non-verbal element (18 with an adverbials or a conjunction and 11 with objects). Examples of this are provided in (13):

(13) a. eh $\mathrm{du}$ kanske har lite frågor att komma med
eh you maybe have little questions to come with (Swedish) 'Eh, maybe you have a few questions to ask.' (viby_om1)

b. nu kanske det har vänt (Swedish) now maybe it has turned

'Maybe it has turned now.' (bengtsfors_om1)

c. nja det kanske den gjorde (Swedish)

well that maybe it did

'Well, maybe it did that.' (st_anna_om2)

Only three out of the 60 (non-V2) hits in Swedish display the order where maybe is the very initial element in the clause. This is illustrated in (14):

(14) a. kanske du undrar vad det är

(Swedish)

maybe you wonder what it is

'Maybe you wonder what it is.' (torso_om2)

b. kanske han ordnar något

(Swedish)

maybe he arranges something

'Maybe he will arrange something.' (vaxtorp_ym3)

Thus, in contrast to Norwegian, pattern (6iii), where maybe is predeced by the subject or some other nonverbal element is by far the most common non-V2 pattern in clause with initial maybe.

Now let us return to the two potential V2 examples in the Swedish material. These examples are illustrated in (15). Although they indeed display the finite verb in the second position, following initial 'maybe', there is no overt subject in either of the sentences. Most likely, both these sentences feature topic drop of a topical sentence, expletive det 'it' in (15a) and han 'he' in (15b). It is of course difficult to determine from which position these topics have been dropped. However, such topic drop typically applies to elements in the left edge of the clause (Sigurðsson \& Maling 2008, Sigurðsson 2011). Thus, it seems likely that the topics originate in a position preceding (or possibly following) 'maybe'. On these 
assumptions, also the apparent examples of the V2 word order in (15) are actually instances of the nonV2 type of word order.

a. kanske var lika bra att inte ha reda på det (Swedish)
maybe was equally good to not have clarity on it

[det kanske var lika bra att inte ha reda på det]

'It was perhaps just as well not to know anything about it.' (orust_om3)

b. kanske är lite för smal för byxan som är vidare än han är (Swedish)
maybe is little too slim for pants.DEF which are wider than he is

[han kanske är lite för smal för byxan som är vidare än han är]

'Maybe he is a bit too slim for the pants, which are wider that he is.' (leksand_ow3)

\section{Discussion}

According to the literature on this phenomenon, lack of V2 is supposed to be possible in clauses introduced by adverbial maybe in most of the Scandinavian languages (see references above). However, it has been claimed to be absent at least very infrequent in Danish. Based on written texts, Andréasson (2002) and Beijering (2010) show that although V2 is more frequent than non-V2 in clauses with initial 'maybe,' the non-V2 word order certainly occurs in these clauses as well, as least in Swedish and Norwegian. In Danish, on the other hand, hardly any instances of non-V2 are found.

For Norwegian, data from spoken language show a somewhat different pattern. Westergaard (2009) investigated word order in this type of clause in Norwegian spoken language. Her data comes from four adult speakers in the Anderssen corpus of Northern Norwegian child language (Anderssen 2006) and the NoTa corpus (166 adults speaking the Oslo dialect). In this material, Westergaard found that the non-V2 word order was much more frequent than the V2 word order in clauses introduced by maybe, occurring 93.5\%, $98.1 \%$ and $100 \%$ of the time in the Anderssen corpus, and $95.4 \%$ of the time in the NoTa corpus. Thus, according to Westergaard's study non-V2 is by far the more common word order in clauses introduced by maybe in spoken Norwegian. There are no parallel studies of spoken language for any of the other Scandinavian languages.

The data in the Nordic Syntax Database and the Nordic Dialect Corpus to a large extent corroborate the results reported in previous studies. As mentioned above, the Scandinavian languages are V2 languages, and the finite verb typically appears in the second position in main clauses. In clauses that do not display V2 the Scandinavian languages split into two groups: In Icelandic such clauses display V-to-I movement, whereas in Mainland Scandinavian, there is typically no verb movement independent of V2. V-to-I movement independent of V2 was found in all the Scandinavian languages until the 16th-17th centuries, when this phenomenon gradually started to decline in MSc (cf. among others Sundquist 2003). Although this word order remained in Insular Scandinavian, and is still today a central feature of 
Icelandic, Faroese is currently at the tail end of a change involving the loss of independent V-to-I movement. According to Heycock et al. (2010, 2011), the word order pattern is more or less lost today. Based on fieldwork, Bentzen et al. (2009) argue that the pattern might be slightly more in use or acceptable in the North than in other parts of the country (note that this is in contrast with the claims made in Jonas 1996). This position seems to be supported by the current data, where exactly the two Northern locations are the ones where V-to-I is preferred over V2.

The Nordic Syntax Database shows that, as expected, the V-to-I movement illustrated in (3) is not accepted in either Denmark or Norway. This type of verb movement is lost in the Mainland Scandinavian languages, and clauses introduced by maybe are no exception in this respect. In Danish, lack of verb movement is also usually rejected or degraded in clauses introduced by maybe; V2 is required. In the four locations where this was tested in Norway, the clauses without any verb movement are typically accepted alongside the option of V2. In the Nordic Dialect Corpus, the vast majority of sentences introduced by maybe show non-V2 in Norwegian and Swedish, while in the very few examples attested Danish, Icelandic and Faroese, both V2 and non-V2 word orders are found.

In Faroese, lack of verb movement was not tested; we thus cannot tell from the judgment data whether this is an option in Faroese or not. Interestingly, with respect to the two word order patterns, we find a geographical split. While the informants in the very southernmost location, Hvalba, give high scores to both word orders, the Northern locations, Viðareiði and Fulgafjørður, seem to prefer V-to-I (and only marginally accept V2), and the locations in the middle of the country, Tórshavn, Sandur, and Miðvagur, show the opposite pattern, preferring V2 (and only marginally accepting V-to-I). None of the three non-V2 examples attested in the Nordic Dialect Corpus contained negation (or other clause-medial adverbs), so these examples could not reveal anything about V-to-I movement. Furthermore, the sample is too small to allow us to make any generalizations concerning geographical variation.

The search in the Nordic Dialect Corpus moreover revealed a striking difference between Norwegian and Swedish with regards to the distribution of non-V2 word order patterns in these clauses with an initial maybe. In Norwegian, the preferred option is clearly the one in which maybe is the very initial element in the clause, as exemplified in (10). This pattern is used in 99 out of the 122 non-V2 word orders ( $81 \%$ of the time) in Norwegian. In contrast, in Swedish, the by far most frequent word order in these non-V2 clauses is the type where maybe is preceded by the subject or some other non-verbal element, as illustrated in (13). In Swedish, this pattern is used in 57 out of 60 cases (95\% of the time).

A final interesting point about these data is that in Norwegian, while lack of verb movement is accepted both with pronominal subjects and DP subjects in the tested clauses, when the subject is a DP, lack of verb movement is the only option. That is, in clauses introduced by adverbial maybe with a DP subject, V2 is not possible. Thus, this seems to constitute one of the rare cases in which V2 is in fact banned in a matrix declarative clause in Norwegian. 


\section{References}

Anderssen, Merete. 2006. The Acquisition of Compositional Definiteness in Norwegian. Doctoral Dissertation, University of Tromsø.

Andréasson, Maia. 2002. 'Kanske - en vilde i satsschemat.' (= Meddelanden från Institutionen för svenska språket 41). Göteborg: Institutionen för Svenska Språket.

Beijering, Karin. 2010. 'The grammaticalization of Mainland Scandinavian MAYBE,' Bergen Language and Linguistics Studies.

Bentzen, Kristine, Piotr Garbacz, Caroline Heycock, and Gunnar Hrafn Hrafnbjargarson. 2009. 'On variation in Faroese verb placement.' In Peter Svenonius, Kristine Bentzen, Jógvan í Lon Jacobson, Janne Bondi Johannessen, Caroline Heycock, Jeffrey Parrott, Tania E. Strahan, and Øystein Vangsnes (eds.) Nordlyd 36.2: NORMS Papers on Faroese: 78-102.

Bentzen, Kristine. 2014. 'Subject placement with respect to negation,' Nordic Atlas of Linguistic Structures (NALS). http://www.tekstlab.uio.no/nals\#/chapter/54.

Faarlund, Jan Terje, Svein Lie and Kjell Ivar Vannebo. 1997. Norsk referansegrammatikk. Universitetsforlaget, Oslo.

Heycock, Caroline, Antonella Sorace and Zakaris Hansen. 2010. 'V-to-I and V2 in subordinate clauses: An investigation of Faroese in relation to Icelandic and Danish,' Journal of Comparative Germanic Linguistics 13, 61-97.

Heycock, Caroline, Antonella Sorace, Zakaris Hansen, Frances Wilson, and Sten Vikner. 2011. 'Residual V-to-I in Faroese and its lack in Danish: Detecting the final stages of a syntactic change,' Working Papers in Scandinavian Syntax 87, 137-165.

Jonas, Diane. 1996. Clause structure and verb syntax in Scandinavian and English. PhD thesis, Harvard University.

Platzack, Christer. 1986. 'The position of the finite verb in Swedish.' In Hubert Haider and Martin Prinzhorn (eds.) Verb Second Phenomena in Germanic Languages. Foris, Dordrecht, 27-47.

Platzack, Christer. 1998. Svenskans inre grammatik - det minimalistiska programmet. En introduktion till modern generativ grammatik. Lund: Studentlitteratur.

Rögnvaldsson, Eiríkur and Höskuldur Thráinsson, 1990. 'On Icelandic word order once more,' in Joan Maling and Annie Zaenen (eds.) Modern Icelandic Syntax, Syntax and Semantics 24. Academic Press, San Diego, 3-40.

Sigurðsson, Halldór Àrmann and Joan Maling. 2008. 'Argument drop and the Empty Left Edge Condition (ELEC),' Working Papers in Scandinavian Syntax 81, 1-27.

Sigurðsson, Halldór Ármann. 2011. 'Conditions on argument drop,' Linguistic Inquiry 42.2, 267-304.

Sundquist, John D. 2003. 'The Rich Agreement Hypothesis and Early Modern Danish embedded-clause word order,' Nordic Journal of Linguistics 26 2: 233-258.

Teleman, Ulf, Staffan Hellberg and Erik Andersson. 1999. Svenska Akademiens Grammatik. Svenska Akademien, Stockholm. 
Thráinsson, Höskuldur, Hjalmar Petersen, Jógvan í Lon Jacobsen and Zakaris Svabo Hansen. 2004.

Faroese. An Overview and Reference Grammar. Føroya Fróðskaparfelag, Tórshavn.

Westergaard, Marit. 2009. 'Microvariation as Diachrony: A View from Acquisition,' Journal of

Comparative Germanic Linguistics 12.1, 49-79.

\section{Web sites:}

Nordic Atlas of Language Structures (NALS) Journal: http://www.tekstlab.uio.no/nals

Nordic Dialect Corpus: http://www.tekstlab.uio.no/nota/scandiasyn/index.html

Nordic Syntax Database: http://www.tekstlab.uio.no/nota/scandiasyn/index.html 